\title{
RADIOCARBON CONCENTRATIONS OF WOOD ASH CALCITE: POTENTIAL FOR DATING
}

\author{
Lior Regev ${ }^{1}$ Eileen Eckmeier ${ }^{2,3}$ • Eugenia Mintz ${ }^{2}$ Steve Weiner ${ }^{1}$ Elisabetta Boaretto ${ }^{2,4}$ \\ ABSTRACT. Ash is formed when plant calcium oxalate crystals $\left(\mathrm{CaC}_{2} \mathrm{O}_{4}\right)$ decompose to form calcite $\left(\mathrm{CaCO}_{3}\right)$. We found \\ that ash does retain the original calcium oxalate radiocarbon concentration, but in addition, there is another minor ${ }^{14} \mathrm{C}$ source. \\ This is shown by the presence of a consistent small shift in the pMC and $\delta^{13} \mathrm{C}$ levels when comparing cellulose and ash from \\ modern and archaeological woods. Possible mechanisms for ${ }^{14} \mathrm{C}$ exchange during combustion or due to diagenesis are con- \\ sidered in order to define parameters for identifying better-preserved wood ash samples.
}

\section{INTRODUCTION}

Wood ash is often an abundant component of the archaeological record of many sites. The major inorganic component of wood ash is calcite. Other minor inorganic components include the siliceous aggregates and silica phytoliths (Weiner 2010). Wood ash may be dispersed and mixed with other sediments, or may form distinct layers. The distinct layers should represent well-defined contexts within the site stratigraphy, and thus radiocarbon dating the ash calcite of these layers would contribute significantly to a better understanding of the absolute chronology of the site.

The wood ash may also contain charcoal fragments, if the combustion process was incomplete. To date, ${ }^{14} \mathrm{C}$ dating of wood ash has been restricted to dating the charcoal component. Charcoal, however, is often not present in ash accumulations. There is therefore much interest in dating the major calcitic component itself.

Wood ash calcite forms when the biogenic calcium oxalate monohydrate (whewellite crystals, $\mathrm{CaC}_{2} \mathrm{O}_{4} \cdot \mathrm{H}_{2} \mathrm{O}$ ) present in the wood and bark decomposes to calcite and carbon monoxide (CO) at around $450^{\circ} \mathrm{C}$ during combustion (Dollimore 1987; Huaqing 1989; Frost and Weier 2004). This calcite should, in principle, retain the original carbon atoms sequestered by the plant from the atmosphere during photosynthesis, provided that it was not subsequently altered diagenetically. Thus, pristine ash calcite should also retain the ${ }^{14} \mathrm{C}$ signal of the atmosphere at the time the tree formed the calcium oxalate crystals (Franceschi and Nakata 2005). This in turn implies that the age of the ash should be identical to the age of the source wood. An ash calcite ${ }^{14} \mathrm{C}$ date would thus suffer from the well-known "old wood effect" (Schiffer 1986; Bowman 1990:15). Note that the fuel used at a specific location could originate from various sources, such as from different parts of trees with different ages, from grasses and dung. This would produce ash calcite with heterogeneous ages.

If the wood was burned at a high temperature, i.e. over $\sim 750^{\circ} \mathrm{C}$, the ash calcite that was formed at $450{ }^{\circ} \mathrm{C}$ would be calcined. During this process, the calcite loses carbon dioxide $\left(\mathrm{CO}_{2}\right)$, resulting in the formation of calcium oxide (CaO, quicklime), as occurs in lime plaster formation (Boynton 1980; Frost and Weier 2004). When exposed to water or even to the atmospheric humidity, the quicklime slakes to form calcium hydroxide $\left(\mathrm{Ca}(\mathrm{OH})_{2}\right)$, which dries and absorbs carbon dioxide from the atmosphere over time, forming calcite again (Boynton 1980). This high-temperature ash calcite thus con-

\footnotetext{
${ }^{1}$ Department of Structural Biology and the Kimmel Center for Archaeological Science, Weizmann Institute of Science, Rehovot 76100 , Israel.

${ }^{2}$ Radiocarbon and Cosmogenic Isotopes Laboratory, Kimmel Center for Archaeological Science, Weizmann Institute of Science, 76100 Rehovot, Israel.

${ }^{3}$ INRES - Soil Science and Soil Ecology, University of Bonn, 53115 Bonn, Germany.

${ }^{4}$ Department of Land of Israel Studies and Archaeology, Bar-Ilan University, Ramat-Gan 52900, Israel. Corresponding author. Email: elisabetta.boaretto@weizmann.ac.il.
} 
tains ${ }^{14} \mathrm{C}$ from the atmosphere at the time of combustion, and should not be affected by the "old wood effect." Such high-temperature ash calcite could be produced in kilns and other high-temperature installations, but presumably not in hearths and cooking installations. As part of an anthropological study, Lyons and D’Andrea (2003) measured the temperature of cooking installations in Ethiopia. While the temperature at the cooking point was $300-600{ }^{\circ} \mathrm{C}$, the temperature in the ash did not exceed $200^{\circ} \mathrm{C}$. Either way, the temperature in the measured cooking installations did not reach the $750{ }^{\circ} \mathrm{C}$ required for calcination. Note that if the ash calcite crystals are relatively well preserved, lowand high-temperature archaeological ash calcite can be differentiated based on the extent of atomic disorder in their crystal lattices, using a new infrared spectroscopic method (Regev et al. 2010).

Very few attempts to ${ }^{14} \mathrm{C}$ date ash calcite have been published. In one case, carbonates from a sequence of hearths and soils were dissolved, the $\mathrm{CO}_{2}$ was extracted, and dated (Koumouzelis et al. 2001). All the carbonate samples yielded younger ages than the dates obtained from associated organic samples. This difference was attributed to subsequent deposition of carbonates or secondary cementation processes (Koumouzelis et al. 2001).

Several difficulties may complicate the process of dating archaeological wood ash produced at around $500{ }^{\circ} \mathrm{C}$, over and above the "old wood effect." Minor difficulties may arise from the possibility that calcium oxalate crystals form over a long period of time while the tree is living, and possibly undergo some isotopic exchange during this period. More significantly, it is conceivable that there is an exchange of $\mathrm{CO}$ molecules between the wood ash and the air during the combustion process (Price et al. 1980). A high-temperature exchange process between $\mathrm{CO}_{2}$ and bone mineral is suspected to occur for cremated bones (Zazzo et al. 2009). In the case of silicates minerals (e.g. phytoliths and diatoms), recent studies indicate that these materials interact with the $\mathrm{CO}_{2}$ in the environment and change the original ${ }^{14} \mathrm{C}$ content (Hatté et al. 2010; Santos et al. 2010). Furthermore, when dealing with archaeological ash samples, a serious difficulty is the problem encountered by Koumouzelis et al. (2001) and when dating calcitic plaster/mortar (Lindroos et al. 2007), namely that the crystals are relatively unstable and undergo diagenetic alteration that results in the original ${ }^{14} \mathrm{C}$ concentration changing over time.

Here, we present the ${ }^{14} \mathrm{C}$ concentrations of modern and ancient wood ash samples that were burned in the laboratory at $500{ }^{\circ} \mathrm{C}$ and $900^{\circ} \mathrm{C}$, as well as modern and archaeological ash samples. The ages of the fossil ash samples were known in order to enable the detection of exchange and/or diagenetic processes.

\section{MATERIALS AND METHODS}

\section{Materials}

Tree rings from a pine tree (Pinus halepensis) were extracted from a slice of a large tree trunk that was cut down on the campus of the Weizmann Institute of Science (Rehovot, Israel) in 2002. Rings 5, 17-19, and 50-52 were milled into powder. Modern wood trunks of various tree species were obtained from the Keren Kayemeth Leyisrael and were used as fuel for open bonfires to produce modern ash samples. The species types were not documented. However, all wood came from trunks and branches over 7-10 cm in diameter. Archaeological wood samples were obtained from 2 locations: a piece of Maerua crassifolia wood, excavated by Profs Richard Freund and Rami Arav, at the 2000-yr-old site of the Cave of Letters (Dead Sea area, Israel), and a 6th century CE cedar tree (Cedrus libani) from a building in Jerusalem, sampled by one of us. Rings 32-41 of this cedar wood were milled. Archaeological ash samples were collected from the Natufian strata of Hayonim Cave (upper-west Galilee, Israel): sample HAY2000 was taken from square P28a/P27c (collected during 
excavation in 2000) and sample EHY2 from square M24, Locus 8 freshly collected in 2009. The Natufian culture in Israel existed between 13,000-10,200 BP (Belfer-Cohen 1991; Bar-Yosef 2002).

\section{Methods}

Cellulose Extraction: The method is based on Gupta and Polach (1985:24-26). Some $200 \mathrm{~mL}$ of Nanopure water (NANOpure Diamond ${ }^{\mathrm{TM}}$, Barnstead) and $20 \mathrm{~mL}$ of $1 \mathrm{~N} \mathrm{HCl}$ were added to $20-25 \mathrm{~g}$ of milled wood, and placed with a stirrer on an $80^{\circ} \mathrm{C}$ hot plate. Sodium chlorite (Fluka 71388-250g) was gradually added until no more wood pieces were observed. The solution was diluted by an additional $1.5 \mathrm{~L}$ of Nanopure water and was left for $16 \mathrm{hr}$. The following day, the supernatant was discarded, and the cellulose was centrifuged and dried at $105^{\circ} \mathrm{C}$. It was subsequently burnt in a calorimetric bomb to produce $\mathrm{CO}_{2}$, which was chemically transformed to benzene for ${ }^{14} \mathrm{C}$ measurement using a liquid scintillation counter.

Modern Wood (Pine Tree Rings) - Ring Counting, Burning, and ${ }^{14} \mathrm{C}$ Concentration Measurements: Based on tree-ring counting, we estimated the age of the tree as $52 \mathrm{yr}$ (Figure 1). Note that the ring pattern was not compared with neighboring trees, and the counting of the rings has a precision of \pm 1 to 2 rings. About $20 \mathrm{~g}$ of each milled sample (Figure 1) were used for cellulose extraction and dating. An additional $20 \mathrm{~g}$ were burnt at $500{ }^{\circ} \mathrm{C}$ for $1 \mathrm{hr}$ to produce ash. About $120 \mathrm{mg}$ of ash were obtained, from which $\sim 60 \mathrm{mg}$ remained after one wash with Nanopure water. The resulting ash was mainly calcitic and was dissolved in phosphoric acid for $16 \mathrm{hr}$ at $40{ }^{\circ} \mathrm{C}$ to release $\mathrm{CO}_{2}$, which was subsequently chemically transformed into graphite for accelerator mass spectrometry (AMS) dating.

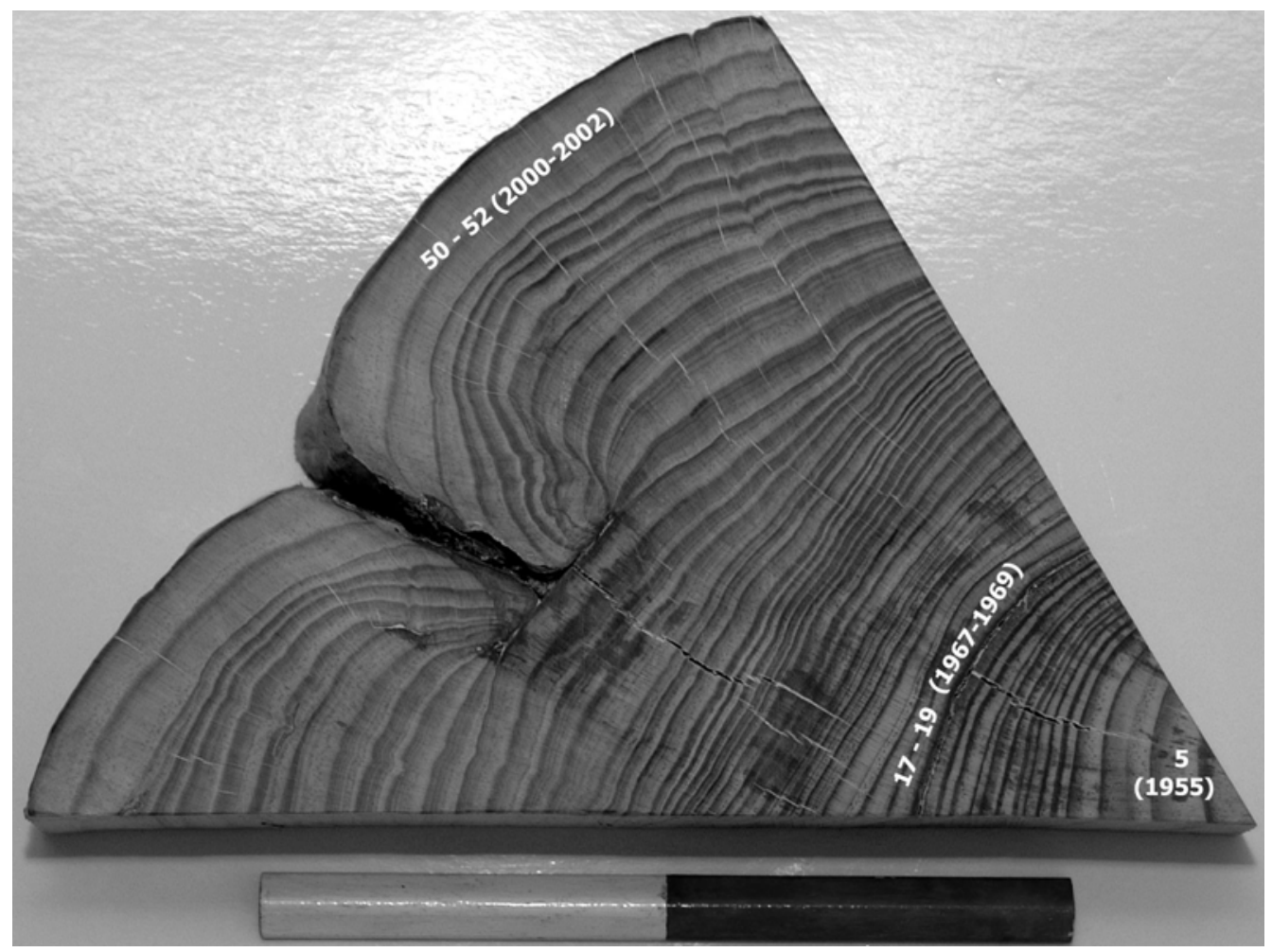

Figure 1 A section of a pine tree trunk that was cut down in 2002. Some 52 rings were counted. Note that the first 3 growth rings are not shown in this piece. The sampled rings and their expected growth years are marked. Scale is $20 \mathrm{~cm}$. 
Archaeological Wood from the Cave of Letters: Cellulose was extracted and dated in 2001. In order to produce ash, $18 \mathrm{~g}$ of the wood sample were milled, burned, and prepared for dating as above. For high-temperature ash production, $25 \mathrm{~g}$ of the wood were milled and burned at $900{ }^{\circ} \mathrm{C}$ for $1 \mathrm{hr}$ in December 2008. For recarbonation, the sample was left in an open $50-\mathrm{mL}$ tube, horizontally oriented, forming a layer a few mm thick. The tube was left on the laboratory shelf at a room temperature of $20-25^{\circ} \mathrm{C}$ for 9 months. The environmental conditions were not monitored. The sample was dated following the method used for the ash from the pine tree rings.

Modern Ash from an Open Bonfire: An open fire was made in Rehovot, Israel, in January 2007. The fire was made on a tiled surface in order to avoid sediment contamination of the ash. About $100 \mathrm{~kg}$ of wood were used. The fire was kept burning for $8 \mathrm{hr}$ and then allowed to die down without the addition of water. The temperature was measured every $15 \mathrm{~min}$ in the middle of the fire, about $10 \mathrm{~cm}$ above ground level. The average temperature of the flames was $840^{\circ} \mathrm{C}$. The air pressure was $1.0 \mathrm{~atm}$ and the wind speed was $1.5-2 \mathrm{~m}$ per second. The ash was collected the next morning after cooling overnight and kept in the laboratory in closed bags. An ash sample from the open bonfire was sieved through a 1-mm mesh in order to remove the larger charcoal fragments. Some $20 \mathrm{~g}$ of the sieved material were dissolved with $5 \mathrm{~N} \mathrm{HCl}$ for $\mathrm{CO}_{2}$ extraction and chemically transformed (through $\mathrm{Li}_{2} \mathrm{C}_{2}$ and $\mathrm{C}_{2} \mathrm{H}_{2}$ ) into benzene for liquid scintillation counting (LSC). Some $50 \mathrm{~g}$ of the ash was burnt to $900{ }^{\circ} \mathrm{C}$ in August 2008, for $1 \mathrm{hr}$, and left as a 1- to 3-mm-thick layer in an open box on the laboratory shelf for recarbonation for 12 months. The environmental conditions and the ${ }^{14} \mathrm{C}$ measurement procedure were the same as for the high-temperature ash produced from the Cave of Letters sample.

Archaeological Ash Samples from Hayonim Cave: Sample HAY2000 was separated into different size fractions by sieving through 1.0-, 0.5-, and $0.25-\mathrm{mm}$ mesh sieves. Three fractions were prepared for LSC as above: $0-1 \mathrm{~mm}, 0.25-0.5 \mathrm{~mm}$, and smaller than $0.25 \mathrm{~mm}$. Sample EHY2 was sieved through a $20-\mu \mathrm{m}$ mesh and prepared for AMS dating as above. The ${ }^{14} \mathrm{C}$ dates were calibrated using the OxCal v4.1 online version (Bronk Ramsey 2009; available at http://c14.arch.ox.ac.uk/ embed.php?File=oxcal.html) using IntCal09 calibration curve (Reimer et al. 2009).

Fourier Transform Infrared Spectrometry (FTIR): A few milligrams of sample were homogenized and powdered in an agate mortar and pestle. About $0.3 \mathrm{mg}$ were left in the mortar and mixed with $\sim 40 \mathrm{mg}$ of $\mathrm{KBr}$ and pressed into a 7-mm KBr pellet using a manual hydraulic press (Specac). Each sample was measured repeatedly, either by repetitive grinding of the same $\mathrm{KBr}$ pellet or by using different aliquots of the same sample that were ground to different extents. Both methods produced the same results (Regev et al. 2010). Infrared spectra were obtained at $4-\mathrm{cm}^{-1}$ resolution for 32 scans using a Nicolet 380 instrument (Thermo Scientific). The baselines for the height measurements of the $v_{3}, v_{2}$, and $v_{4}$ peaks were determined following the method of Chu et al. (2008). The $v_{2}$ and $v_{4}$ peak heights were normalized to a $v_{3}$ peak height of 1000 , corresponding to 1.0 Absorbance Unit (Regev et al. 2010). This method was used for all samples presented in Figure $2 \mathrm{~b}$.

\section{RESULTS}

Our strategy was first to determine whether exchange of ${ }^{14} \mathrm{C}$ occurs during the combustion process by analyzing the ${ }^{14} \mathrm{C}$ contents of ash samples produced in an oven from modern wood, followed by ash from modern open fires and ancient woods. We then analyzed archaeological ash samples to evaluate the problem of ash preservation. The results are summarized in Table 1.

\section{Cellulose and Ash ${ }^{14} \mathrm{C}$ Contents}

In order to verify whether calcitic ash maintains the atmospheric ${ }^{14} \mathrm{C}$ concentration of the tree at the time it was formed, we produced ash from modern wood and compared its ${ }^{14} \mathrm{C}$ concentration, given 
Table 1 Description, ${ }^{14} \mathrm{C}$ contents, and $\delta^{13} \mathrm{C}$ values of cellulose and ash wood samples. pMC refers to the percentage of modern carbon (100 pMC is the $\mathrm{AD} 1950$ atmospheric ${ }^{14} \mathrm{C} /{ }^{12} \mathrm{C}$ concentration).

\begin{tabular}{|c|c|c|c|c|c|c|}
\hline \multirow[b]{2}{*}{ Type } & \multirow[b]{2}{*}{ Wood type } & \multirow[b]{2}{*}{ Sample name } & \multicolumn{2}{|c|}{ Cellulose } & \multicolumn{2}{|l|}{ Ash } \\
\hline & & & $\mathrm{pMC}$ & $\delta^{13} \mathrm{C}$ & $\mathrm{pMC}$ & $\delta^{13} \mathrm{C}$ \\
\hline \multirow{4}{*}{$\begin{array}{l}\text { Modern ash pro- } \\
\text { duced in an oven at } \\
500{ }^{\circ} \mathrm{C}\end{array}$} & Pinus halepensis & Pine rings 50-52 & $\begin{array}{l}106.89 \pm 0.28 \\
\text { RT } 5724\end{array}$ & $-21.8 \%$ & $\begin{array}{l}106.79 \pm 0.49 \\
\text { RTT } 5834\end{array}$ & \\
\hline & & & & & $\begin{array}{l}105.96 \pm 0.49 \\
\text { RTT } 5835\end{array}$ & $-24.3 \%$ \\
\hline & Pinus halepensis & Pine rings $17-19$ & $\begin{array}{l}145.54 \pm 0.72 \\
\text { RT } 5995.2\end{array}$ & $-22.4 \%$ o & $\begin{array}{l}141.33 \pm 0.70 \\
\text { RTT } 5973\end{array}$ & $-24.0 \%$ о \\
\hline & Pinus halepensis & Pine ring 5 & $\begin{array}{l}108.68 \pm 0.28 \\
\text { RT } 5975\end{array}$ & $-22.5 \%$ о & $\begin{array}{l}105.62 \pm 0.55 \\
\text { RTT } 5974\end{array}$ & $-24.8 \%$ \\
\hline $\begin{array}{l}\text { Ash from archaeo- } \\
\text { logical wood pro- }\end{array}$ & $\begin{array}{l}\text { Maerua crassi- } \\
\text { folia }\end{array}$ & $\begin{array}{l}\text { Cave of Letters } \\
\text { wood ash }\end{array}$ & $\begin{array}{l}78.5 \pm 0.15 \\
\text { RT } 3916\end{array}$ & $-23.7 \%$ & $\begin{array}{l}81.28 \pm 0.47 \\
\text { RTT } 5911.2\end{array}$ & $-23.6 \%$ \\
\hline $\begin{array}{l}\text { duced in an oven at } \\
500^{\circ} \mathrm{C}\end{array}$ & Cedrus libani & $\begin{array}{l}\text { Jerusalem wood } \\
\text { ash, rings 32-41 }\end{array}$ & $\begin{array}{l}83.62 \pm 0.41 \\
\text { RT } 6069.1\end{array}$ & $-20.5 \%$ о & $\begin{array}{l}90.54 \pm 0.47 \\
\text { RTT } 5998\end{array}$ & $-21.3 \%$ \\
\hline $\begin{array}{l}\text { Modern ash pro- } \\
\text { duced in an open fire }\end{array}$ & Various & $\begin{array}{l}\text { Modern bonfire } \\
\text { ash }\end{array}$ & n.a. & n.a. & $\begin{array}{l}112.50 \pm 0.59 \\
\text { RT } 5879\end{array}$ & $-24.5 \%$ \\
\hline \multicolumn{7}{|l|}{ Ash burned at $900^{\circ} \mathrm{C}$} \\
\hline Modern ash & Various & $\begin{array}{l}\text { Modern bonfire } \\
\text { ash } 900^{\circ} \mathrm{C}\end{array}$ & n.a. & n.a. & $\begin{array}{l}102.9 \pm 0.54 \\
\text { RTT } 5993\end{array}$ & $-21.1 \%$ \\
\hline $\begin{array}{l}\text { Ash from archaeo- } \\
\text { logical wood }\end{array}$ & $\begin{array}{l}\text { Maerua crassi- } \\
\text { folia }\end{array}$ & $\begin{array}{l}\text { Cave of Letters } \\
\text { wood ash } 900{ }^{\circ} \mathrm{C}\end{array}$ & $\begin{array}{l}78.5 \pm 0.15 \\
\text { RT } 3916\end{array}$ & $-23.7 \%$ & $\begin{array}{l}102.77 \pm 0.54 \\
\text { RTT } 5994\end{array}$ & $-17.5 \%$ \\
\hline
\end{tabular}

as the percentage of modern carbon (pMC; $100 \mathrm{pMC}$ is the $\mathrm{AD} 1950$ atmospheric ${ }^{14} \mathrm{C} /{ }^{12} \mathrm{C}$ concentration), to that of the extracted cellulose fraction. We used rings from a pine tree that was cut down at the Weizmann Institute of Science (Rehovot, Israel) in 2002 (Figure 1).

Bearing in mind the nuclear explosions conducted in the atmosphere in the late 1950s and early 1960s (reaching a peak in 1964, which doubled the world's atmospheric pMC level), we compared rings from 3 periods. The outermost rings (50-52) reflect the modern atmosphere. Rings 17-19 were formed a few years after the peak of the nuclear tests, and thus should have much higher levels of ${ }^{14} \mathrm{C}$. Ring 5 formed prior to the increase in atmospheric ${ }^{14} \mathrm{C}$ concentration. Pine rings $50-52$ showed excellent agreement between pMC concentrations in cellulose and ash from the same wood. This clearly demonstrates that the calcium oxalate monohydrate crystals do incorporate the pMC levels of the atmosphere at the time they formed, and that this signal is retained during the decomposition and ash formation processes. Pine rings 17-19 and pine ring 5, however, had lower pMC values in the ash as compared to cellulose from the same rings. This shows that during the decomposition process of calcium oxalate to calcite at around $500{ }^{\circ} \mathrm{C}$, there is an exchange with the atmosphere. This was confirmed by the burning of 2 samples of ancient wood at $500^{\circ} \mathrm{C}$ (Table 1 ). In both cases, the ash produced in 2009 from the ancient wood had higher pMC values than the cellulose extracted from the wood. The cellulose represents the $\mathrm{CO}_{2} \mathrm{pMC}$ value of the atmosphere at the time the tree ring was formed. Significantly, the ash produced from these wood samples did not yield the same pMC values for all samples, indicating that when ash is produced at temperatures $\sim 500{ }^{\circ} \mathrm{C}$, only a partial exchange occurs. This is in contrast to the ash that was prepared at $900{ }^{\circ} \mathrm{C}$. The modern bonfire ash and the Cave of Letters ash were both heated to $900^{\circ} \mathrm{C}$, and in both cases their pMC values were those of the present-day modern atmospheric $\mathrm{CO}_{2}$ (Levin and Kromer 2004; Turnbull et al. 2007). This shows that such high-temperature ash totally exchanges with the atmosphere. This ash is formed by the same process by which lime plaster forms. Note that the modern bonfire ash initially had a pMC value higher than the modern atmosphere since a variety of wood logs were used, some of which grew when the atmospheric pMC values were much higher than today. 
The stable carbon isotopic compositions of the cellulose and the ash of all the wood samples produced at $500{ }^{\circ} \mathrm{C}$ are very similar (Table 1 ), and clearly show that the source of the wood ash calcite is indeed the calcium oxalate in the plant and not some other form of inorganic carbon brought into the wood via the roots. However, the $\delta^{13} \mathrm{C}$ of almost all the ash samples is slightly lighter than the cellulose values. It is interesting to note that the 2 ash samples produced at $900{ }^{\circ} \mathrm{C}$ have stable isotopic compositions heavier than the typical cellulose values, and are as expected for calcites formed through the lime plaster pathway (Pachiaudi et al. 1986; Van Strydonck et al. 1989). Note that hightemperature ash eliminates the "old wood effect" since all the carbon atoms are replaced by atmospheric carbon atoms during the process. However, for this to occur, the temperature of the ash itself should exceed $\sim 800^{\circ} \mathrm{C}$. The average flame temperature of the modern open-fire experiment that we conducted was $840^{\circ} \mathrm{C}$ over $8 \mathrm{hr}$. This temperature was measured $10 \mathrm{~cm}$ above ground level. Based on the $\delta^{13} \mathrm{C}$ value of the produced ash (-24.5\%, Table 1$)$, the presence of a small infrared absorption peak of $\mathrm{Ca}(\mathrm{OH})_{2}$ at $3643 \mathrm{~cm}^{-1}$, and the fact that calcite was the major mineral phase a day after the fire, we infer that only a small fraction of the ash decomposed to $\mathrm{CaO}$ during the heating process. In this case, the ${ }^{14} \mathrm{C}$ signal reflects mainly the original ${ }^{14} \mathrm{C}$ levels of the wood.

\section{Diagenesis of Wood Ash}

Another challenge in dating wood ash is to identify samples that have not undergone any diagenesis, or at least have been only minimally affected by diagenesis. During diagenesis, the ash carbonate might dissolve and reprecipitate while absorbing foreign carbonates from the air and ground that will alter the original ${ }^{14} \mathrm{C}$ content.

We first separated the ash samples collected from the Natufian strata in Hayonim Cave (Israel) into 3 size fractions on the assumption that the larger grains would derive mainly from recrystallized calcite, and the fine-grained fraction from the original ash calcite. Table 2 shows that the smallest-sized fraction $(<0.25 \mathrm{~mm})$ has the lowest stable carbon isotopic composition and the highest pMC contents. This implies that it is indeed better preserved than the larger-sized fractions, but as the $\delta^{13} \mathrm{C}$ value is clearly above the value expected for wood, it must have undergone significant diagenesis. Note that the $\delta^{13} \mathrm{C}$ value obtained $\left(-16.8 \%\right.$ ) could be consistent with a $\mathrm{C}_{4}$ type plant origin (Smith and Epstein 1971; Oleary 1988). Hayonim Cave, however, is located in northern Israel, within the Mediterranean phytogeographical region, which is occupied mainly by $\mathrm{C}_{3}$ plants (Shomer-Ilan et al. 1981). Therefore, $\delta^{13} \mathrm{C}$ values of around $-25 \%$ were expected.

Table $2{ }^{14} \mathrm{C}$ ages of archaeological ash and charcoal from the Natufian period at Hayonim Cave (Israel).

\begin{tabular}{|c|c|c|c|c|c|c|c|}
\hline $\begin{array}{l}\text { Sample } \\
\text { name }\end{array}$ & $\begin{array}{l}\text { Sample } \\
\text { type }\end{array}$ & Lab nr & $\mathrm{pMC}$ & $\begin{array}{l}{ }^{14} \mathrm{C} \text { age } \\
\text { (yr BP) }\end{array}$ & $\begin{array}{l}\text { Calibrated age } \\
\mathrm{BP} \pm 1 \sigma\end{array}$ & $\begin{array}{l}\text { Calibrated age } \\
\mathrm{BP} \pm 2 \sigma\end{array}$ & $\begin{array}{l}\delta^{13} \mathrm{C} \\
\% \text { PDB }\end{array}$ \\
\hline $\begin{array}{l}\text { HAY2000 } \\
<1 \mathrm{~mm}\end{array}$ & Ash & RT 5890 & $15.17 \pm 0.26$ & $15,150 \pm 140$ & $18,600-18,080$ & $18,660-18,000$ & $-13.8 \%$ \\
\hline $\begin{array}{l}\text { HAY } 2000 \\
0.25-0.5 \mathrm{~mm}\end{array}$ & Ash & RT 5937 & $10.81 \pm 0.19$ & $17,870 \pm 140$ & $21,530-21,170$ & $21,750-20,800$ & $-10.2 \%$ \\
\hline $\begin{array}{l}\text { HAY2000 } \\
<0.25 \mathrm{~mm}\end{array}$ & Ash & RT 5938 & $16.75 \pm 0.17$ & $14,350 \pm 80$ & $17,610-17,230$ & $17,830-17,120$ & $-16.8 \%$ \\
\hline $\begin{array}{l}\text { EHY2 } \\
<0.02 \mathrm{~mm}\end{array}$ & Ash & RTT 6120 & $26.89 \pm 0.22$ & $10,550 \pm 70$ & $12,575-12,420$ & 12,647-12,375 & $-23.9 \%$ \\
\hline EHY7 & Charcoal & RTT 6129.1 & & $12,260 \pm 70$ & $14,244-13,966$ & $14,596-13,883$ & $-25.5 \%$ \\
\hline EHY12 & Charcoal & RTT 6130.1 & & $12,470 \pm 70$ & $14,781-14,464$ & $15,044-14,162$ & $-27.0 \%$ \\
\hline EHY12 & Charcoal & RTT 6130.2 & & $12,210 \pm 70$ & $14,171-13,942$ & $14,525-13,831$ & $-27.4 \%$ o \\
\hline
\end{tabular}



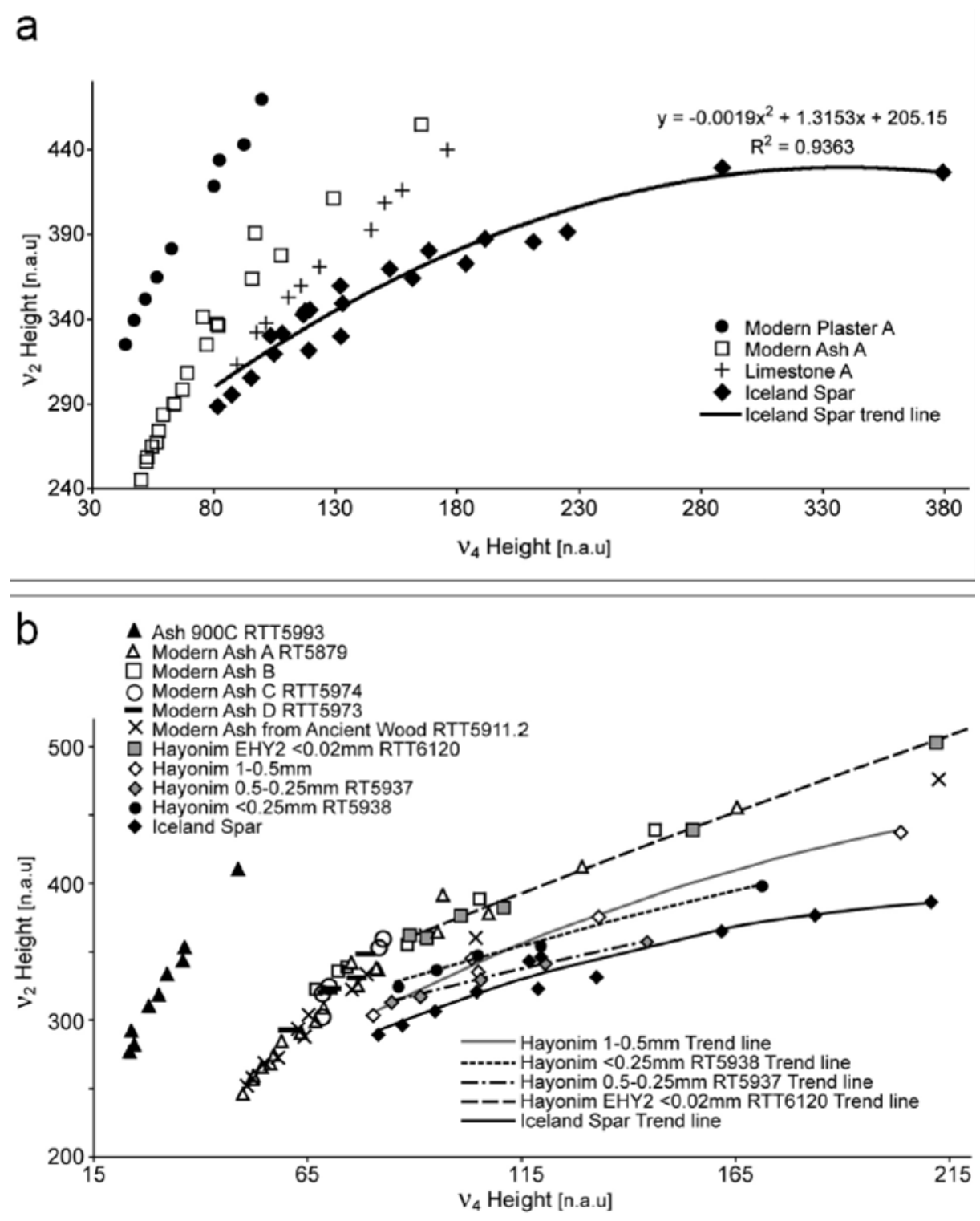

Figure 2 (a) Plot of the $v_{2}$ versus $v_{4}$ peak heights of geogenic and pyrogenic calcites after each spectrum was normalized to the corresponding $v_{3}$ peak height. For each type of calcite, data points correspond to successive grindings of the same specimen. Adapted from Regev et al. (2010). (b) Plot of the $v_{2}$ versus $v_{4}$ peak heights of the calcitic fraction from ash samples. The trend line of the EHY2 sample correlated with the position of modern ash samples (n.a.u. $=$ normalized absorbance units).

We surveyed a series of ash samples (small-size fraction $<0.02 \mathrm{~mm}$ ) from Hayonim Cave using a newly developed infrared spectroscopic method for evaluating the extent of atomic disorder (Regev et al. 2010). Figure 2a demonstrates that calcites formed through different pathways can be distinguished by certain parameters of their infrared absorbance spectrum. When each sample is ground and measured repetitively, trend lines specific for each sample are formed. Interestingly, the geogenic samples (e.g. limestone and Iceland spar) fall on one side of the plot, while pyrogenic samples 
(such as ash and lime plaster) fall on the other side. Figure 2b shows the trend lines obtained after repeated grinding and measurement of the samples for modern ash, the Hayonim Cave ash samples (HAY2000 samples and 1 additional sample [EHY2 size fraction $<0.02 \mathrm{~mm}$ ), as well as the highly ordered Iceland spar calcite. The EHY2 sample trend line falls on the modern ash trend line and above the trend lines for the different size fractions of the HAY2000 samples, which are located closer to the geogenic calcite trend lines. Since the EHY2 ash sample has similar characteristics to modern ash, based on the infrared data, we conclude that the EHY2 small-sized fraction is better preserved than the other ash samples. Furthermore, its stable isotopic composition (Table 2) is essentially the same as the one of wood organic matter. This sample is therefore a good candidate for providing a reliable date, based on these 3 criteria. Its pMC content $(26.89 \pm 0.22)$ corresponds to an uncalibrated ${ }^{14} \mathrm{C}$ age of $10,550 \pm 70 \mathrm{yr} \mathrm{BP}$. After calibration, the age is 12,575-12,420 cal BP $(1 \sigma)$ and 12,645-12,160 cal BP (2 $\sigma)$. Two charcoal samples, taken from lower levels of the same locus, produced dates of 12,200-12,500 yr BP (Table 2), corresponding to a calibrated interval between $14,000-14,700 \mathrm{cal}$ yr BP for $(1 \sigma)$ and 13,800-15,000 cal yr BP $(2 \sigma)$. All these ages are within the expected age range of the Natufian period (Belfer-Cohen 1991; Bar-Yosef 2002).

\section{DISCUSSION}

The results showed that wood ash calcite retains the original carbon of the calcium oxalate mineral produced at the time of growth. However, 2 processes may change the isotopic signature of that carbon and hence the ${ }^{14} \mathrm{C}$ date: exchange with the atmosphere during combustion and post-burial diagenetic processes.

We noted a consistent shift in isotopic composition between the ash and the cellulose. Most ash samples had lower $\delta^{13} \mathrm{C}$ values, and pMC levels that are closer to values from current atmospheric $\mathrm{CO}_{2}$. Since all examined modern ash samples were recently burned in the laboratory or the field, we postulate that such a shift can be explained by an exchange of $\mathrm{CO}$ between the decomposing calcium oxalate crystals and atmospheric $\mathrm{CO}$ during the combustion process.

${ }^{14} \mathrm{CO}$ is the first chemical product of cosmogenic ${ }^{14} \mathrm{C}$, which within a few months is converted to ${ }^{14} \mathrm{CO}_{2}$ by reacting with $\mathrm{OH}$ (Pandow et al. 1960; Weinstock 1969; Rom et al. 2000b). Most atmospheric ${ }^{14} \mathrm{CO}$ is produced in this way. A minor amount of $\mathrm{CO}$ is formed by the oxidation of hydrocarbons that derive from biomass (Rom et al. 2000a). On the other hand, the current widespread use of fossil fuels contributes $\mathrm{CO}$ that contains dead carbon. Therefore, the sampling location is important when collecting an air sample for ${ }^{14} \mathrm{CO}$ measurement. Brenninkmeijer et al. (1992) reported 841 pMC for atmospheric CO collected at a clean-air station in New Zealand during 1989, and Rom et al. (2000b) reported samples with a ${ }^{14} \mathrm{C}$ content of up to $500 \mathrm{pMC}$. Measurements in Los Angeles and its vicinity yielded 20-40 pMC (Sakugawa and Kaplan 1997), and in different areas of Russia $\sim 120$ pMC was measured (Bergamaschi et al. 1998). Our ash samples were prepared in an urban area (the city of Rehovot, Israel; population 100,000), so a mixture of CO sources is expected. A CO exchange mechanism during combustion is also supported by the consistent change in $\delta^{13} \mathrm{C}$ to lighter values in the ash samples, since the $\delta^{13} \mathrm{C}$ value of atmospheric CO is lower than -25\%; typically from -26 to -29\%o (Sakugawa and Kaplan 1997; Bergamaschi et al. 1998; Rom et al. 2000a).

In this study, we compared the $\delta^{13} \mathrm{C}$ values of ash (calcite formed by calcium oxalate decomposition) to those of cellulose and not to the $\delta^{13} \mathrm{C}$ values of the calcium oxalate crystals in the wood. However, a comparison of $\delta^{13} \mathrm{C}$ values between oxalate carbon and whole-leaf organic carbon in 7 Angiosperm species showed that the calcium oxalate isotopic signature is equal ( 1 sample, $-24.8 \%$ ) or heavier (6 samples, $-11.9 \%$ to $-27.9 \%$ ) than the whole-leaf organic carbon. The latter ranged 
from $-22.3 \%$ to $-31.0 \%$ (Raven et al. 1982). By comparing ash $\delta^{13} \mathrm{C}$ values from our study with the oxalate data (Raven et al. 1982), we infer that the shift to lighter isotope values can be attributed to CO exchange during combustion.

In archaeological times, there was no fossil fuel contribution to atmospheric $\mathrm{CO}$, and the $\mathrm{CO} \mathrm{pMC}$ level was much higher than the biospheric ${ }^{14} \mathrm{C}$ concentrations. Therefore, even limited exchange during the burning process of the wood alters the ${ }^{14} \mathrm{C}$ date of the ash, and prevents it from being accurately dated.

There is another possible source of error in dating wood ash. Wood ash contains, in addition to calcite, a few percent by weight of siliceous aggregates and phytoliths (Weiner 2010). These silica minerals have large charged surface areas and a tendency to bind $\mathrm{CO}_{2}$ and most probably $\mathrm{CO}$ from the atmosphere at ambient temperatures. Thus, the presence of this minor fraction in an ash sample could cause a small increase in the pMC, especially during sample preparation, if the sample is exposed to the modern atmosphere.

We used 3 different strategies for identifying the best-preserved ash samples from the Natufian strata of Hayonim Cave. The samples were sieved into different sized fractions, as the smallest size fraction, according to the carbon isotopes concentration, is better preserved than the larger fractions. We then used infrared spectroscopic grinding curves (Regev et al. 2010) to identify samples that have atomic disorder similar to the relatively disordered modern ash samples, and finally we measured the stable isotopic composition of the sample. The latter should reflect the values that are characteristic of wood cellulose rather than the ones typical of atmospheric carbon if diagenetic exchange was low. Although all these criteria do not exclude the possibility that some exchange of carbon has occurred, the obtained calibrated ${ }^{14} \mathrm{C}$ age is well within the Natufian period. However, the 2 charcoal dated samples yielded older dates by nearly $2000 \mathrm{yr}$, and are in agreement with previous published dates from locus 4 of lupine seeds: 12,360 \pm 160 and 12,010 \pm 180 BP (Bar-Yosef 1991). Since EHY2 is situated above the charcoal samples, and its date is in correspondence with the expected time for the end of the Natufian layer in the cave (Bar-Yosef 1991; Bar-Yosef and BelferCohen 1999), it is possible that the date obtained is correct and represents a later occupancy of the Natufian people.

The potential for obtaining reliable dates from wood ash calcite as opposed to plaster/mortar calcite is, in our opinion, more promising as most plaster samples contain, in addition to the calcite fraction produced from $\mathrm{CaO}$, a fraction of partially calcined limestone and/or deliberately added unburnt limestone. Both sources of calcite suffer from their tendency to readily undergo diagenetic alteration. In ash, such deliberate mixing does not occur, and most geogenic calcite from surrounding sediments can be avoided by careful sampling.

\section{CONCLUSIONS}

Ash ${ }^{14} \mathrm{C}$ does retain the original calcium oxalate ${ }^{14} \mathrm{C}$ concentration in the burnt wood, but the presence of an additional ${ }^{14} \mathrm{C}$ source was found. We suggest that the consistent small shift in the pMC and $\delta^{13} \mathrm{C}$ levels is either due to CO crystal-atmosphere exchange during the combustion process or possibly to $\mathrm{CO}$ adsorption to silicates in the ash fraction. The identification of these additional sources is important for assessing the feasibility of ${ }^{14} \mathrm{C}$ ash dating. Another major problem for dating archaeological ash samples is that they are likely to undergo significant post-burial alteration (diagenesis). We present 3 ways for identifying better-preserved wood ash samples that could provide more accurate dates: size fraction separation, infrared analysis, and $\delta^{13} \mathrm{C}$ values. 


\section{ACKNOWLEDGMENTS}

We thank Profs Anna Belfer-Cohen and Ofer Bar-Yosef for their help in obtaining the samples from Hayonim Cave. We thank Profs Rami Arav and Richard Freund for the sample from the Cave of Letters. We thank Mr Ulf Fornhammar for his involvement and initiative in the open-fire experiment. Partial funding was provided by the Kimmel Center for Archaeological Science, Weizmann Institute of Science, the Swiss Society of Friends of the Weizmann Institute, and the European Research Council under the European Community's Seventh Framework Programme (FP7/2007-2013) / ERC grant agreement $n^{\circ} 229418$.

\section{REFERENCES}

Bar-Yosef O. 1991. The archaeology of the Natufian layer at Hayonim Cave. In: Bar-Yosef O, Valla FR, editors. The Natufian Culture in the Levant. Ann Arbor: International Monographs in Prehistory. p 81-93.

Bar-Yosef O, Belfer-Cohen A. 1999. Encoding information: unique Natufian objects from Hayonim Cave, western Galilee, Israel. Antiquity 73(280):402-10.

Bar-Yosef O. 2002. Chapter 5: Natufian - a complex society of foragers. In: Fitzhugh B, Habu J, editors. Beyond Foraging and Collecting: Evolutionary Change in Hunter-Gatherer Settlement Systems. New York: Kluwer Academic. p 91-152.

Belfer-Cohen A. 1991. The Natufian in the Levant. Annual Review of Anthropology 20:167-86.

Bergamaschi P, Brenninkmeijer CAM, Hahn M, Rockmann T, Scharffe DH, Crutzen PJ, Elansky NF, Belikov IB, Trivett NBA, Worthy DEJ. 1998. Isotope analysis based source identification for atmospheric $\mathrm{CH}_{4}$ and $\mathrm{CO}$ sampled across Russia using the TransSiberian railroad. Journal of Geophysical ResearchAtmospheres 103(D7):8227-35.

Bowman S. 1990. Radiocarbon Dating. Interpreting the Past. Berkeley: University of California Press. 63 p.

Boynton RS. 1980. Chemistry and Technology of Lime and Limestone. New York: John Wiley \& Sons. 592 p.

Brenninkmeijer CAM, Manning MR, Lowe DC, Wallace G, Sparks RJ, Volz-Thomas A. 1992. Interhemispheric asymmetry in $\mathrm{OH}$ abundance inferred from measurements of atmospheric ${ }^{14} \mathrm{CO}$. Nature 356(6364):50-2.

Bronk Ramsey C. 2009. Bayesian analysis of radiocarbon dates. Radiocarbon 51(1):337-60.

Chu V, Regev L, Weiner S, Boaretto E. 2008. Differentiating between anthropogenic calcite in plaster, ash and natural calcite using infrared spectroscopy: implications in archaeology. Journal of Archaeological Science 35(4):905-11.

Dollimore D. 1987. The thermal decomposition of oxalates. A review. Thermochimica Acta 117:331-63.

Franceschi VR, Nakata PA. 2005. Calcium oxalate in plants: formation and function. Annual Review of Plant Biology 56:41-71.

Frost RL, Weier ML. 2004. Thermal treatment of whewellite-a thermal analysis and Raman spectroscopic study. Thermochimica Acta 409(1):79-85.
Gupta SK, Polach HA. 1985. Radiocarbon Dating Practices at ANU. Canberra: Radiocarbon Laboratory, Research School of Pacific Studies, Australian National University.

Hatté C, Hodgins G, Holliday VT, Jull AJT. 2010. Dating human occupation on diatom-phytolith-rich sediment: case studies of Mustang Spring and Lubbock Lake, Texas, USA. Radiocarbon 52(1):13-24.

Huaqing L. 1989. Effect of chemical adsorption of calcium oxalate monohydrate on DTA baseline. Thermochimica Acta 141:151-7.

Koumouzelis M, Ginter B, Kozlowski JK, Pawlikowski M, Bar-Yosef O, Albert RM, Litynska-Zajac M, Stworzewicz E, Wojtal P, Lipecki G, Tomek T, Bochenski ZM, Pazdur A. 2001. The Early Upper Palaeolithic in Greece: the excavations in Klisoura Cave. Journal of Archaeological Science 28(5):51539.

Levin I, Kromer B. 2004. The tropospheric ${ }^{14} \mathrm{CO}_{2}$ level in mid-latitudes of the Northern Hemisphere (19592003). Radiocarbon 46(3):1261-72.

Lindroos A, Heinemeier J, Ringbom Å, Braskén M, Sveinbjörnsdóttir A. 2007. Mortar dating using AMS ${ }^{14} \mathrm{C}$ and sequential dissolution: examples from medieval, non-hydraulic lime mortars from the Åland Islands, SW Finland. Radiocarbon 49(1):47-67.

Lyons D, D’Andrea AC. 2003. Griddles, ovens, and agricultural origins: an ethnoarchaeological study of bread baking in highland Ethiopia. American Anthropologist 105(3):515-30.

Oleary MH. 1988. Carbon isotopes in photosynthesis. Bioscience 38(5):328-36.

Pachiaudi C, Marechal J, Van Strydonck M, Dupas M, Dauchot-Dehon M. 1986. Isotopic fractionation of carbon during $\mathrm{CO}_{2}$ absorption by mortar. Radiocarbon 28(2A):691-7.

Pandow M, Mackay C, Wolfgang R. 1960. The reaction of atomic carbon with oxygen: significance for the natural radio-carbon cycle. Journal of Inorganic and Nuclear Chemistry 14(3-4):153-8.

Price D, Dollimore D, Fatemi NS, Whitehead R. 1980. Mass spectrometric determination of kinetic parameters for solid state decomposition reactions. Part 1. Method; calcium oxalate decomposition. Thermochimica Acta 42(3):323-32. 
Raven JA, Griffiths H, Glidewell SM, Preston T. 1982. The mechanism of oxalate biosynthesis in higherplants - investigations with the stable isotopes ${ }^{18} \mathrm{O}$ and ${ }^{13} \mathrm{C}$. Proceedings of the Royal Society of London Series B-Biological Sciences 216(1202):87-101.

Regev L, Poduska KM, Addadi L, Weiner S, Boaretto E. 2010. Distinguishing between calcites formed by different mechanisms using infrared spectrometry: archaeological applications. Journal of Archaeological Science 37(12):3022-9.

Reimer PJ, Baillie MGL, Bard E, Bayliss A, Beck JW, Blackwell PG, Bronk Ramsey C, Buck CE, Burr GS, Edwards RL, Friedrich M, Grootes PM, Guilderson TP, Hajdas I, Heaton TJ, Hogg AG, Hughen KA, Kaiser KF, Kromer B, McCormac FG, Manning SW, Reimer RW, Richards DA, Southon JR, Talamo S, Turney CSM, van der Plicht J, Weyhenmeyer CE. 2009. IntCal09 and Marine09 radiocarbon age calibration curves, 0-50,000 years cal BP. Radiocarbon 51(4): 1111-50.

Rom W, Brenninkmeijer CAM, Bräunlich M, Golser R, Mandl M, Kaiser A, Kutschera W, Priller A, Puchegger S, Röckmann T, Steier P. 2000a. A detailed 2-year record of atmospheric ${ }^{14} \mathrm{CO}$ in the temperate northern hemisphere. Nuclear Instruments and Methods in Physics Research B 161-163:780-5.

Rom W, Brenninkmeijer CAM, Bronk Ramsey C, Kutschera W, Priller A, Puchegger S, Röckmann T, Steier P. 2000b. Methodological aspects of atmospheric ${ }^{14} \mathrm{CO}$ measurements with AMS. Nuclear Instruments and Methods in Physics Research B 172(14):530-6.
Sakugawa H, Kaplan IR. 1997. Radio- and stable-isotope measurements of atmospheric carbon monoxide in Los Angeles. Geochemical Journal 31(2):75-83.

Santos GM, Alexandre A, Coe HHG, Reyerson PE, Southon JR, De Carvalho CN. 2010. The phytolith ${ }^{14} \mathrm{C}$ puzzle: a tale of background determinations and accuracy tests. Radiocarbon 52(1):113-28.

Schiffer MB. 1986. Radiocarbon dating and the "old wood" problem: the case of the Hohokam chronology. Journal of Archaeological Science 13(1):13-30.

Shomer-Ilan A, Nissenbaum A, Waisel Y. 1981. Photosynthetic pathways and the ecological distribution of the Chenopodiaceae in Israel. Oecologia 48(2):244-8.

Smith BN, Epstein S. 1971. Two categories of ${ }^{13} \mathrm{C} /{ }^{12} \mathrm{C}$ ratios for higher plants. Plant Physiology 47(3):380-4.

Turnbull JC, Lehman SJ, Miller JB, Sparks RJ, Southon JR, Tans PP. 2007. A new high precision ${ }^{14} \mathrm{CO}_{2}$ time series for North American continental air. Journal of Geophysical Research-Atmospheres 112(D11): D11310.

Van Strydonck M, Dupas M, Keppens E. 1989. Isotopic fractionation of oxygen and carbon in lime mortar under natural environmental conditions. Radiocarbon 31(3):610-8.

Weiner S. 2010. Microarchaeology - Beyond the Visible Archaeological Record. New York: Cambridge University Press. 396 p.

Weinstock B. 1969. Carbon monoxide: residence time in the atmosphere. Science 166(3902):224-5.

Zazzo A, Saliège J-F, Person A, Boucher H. 2009. Radiocarbon dating of calcined bones: Where does the carbon come from? Radiocarbon 51(2):601-11. 